\title{
ANALISIS PERBANDINGAN KINERJA KEUANGAN PEMERINTAH BOJONEGORO DAN JOMBANG TAHUN 2010-2014
}

\author{
JAENURI \\ PT. Bank Rakyat Indonesia (BRI) Tuban \\ Email: Jaenuriumm12@gmail.com
}

\begin{abstract}
The research is aimed to find out about financial performance between Bojonegoro Regency and Jombang Regency Government in year 2010-2014. The research is done in Bojonegoro Regency and Jombang Regency, data used is collected by documentation on Regional Expenditure and Income Budget (APBD) of Bojonegoro Regency and Jombang Regency. Analysis technique used in this research is descriptive quantitative. Analysis shows that financial performance in Bojonegoro regency is better than Jombang regency. It can be seen from: 1 . Average financial independency ratio. 2. Average of Regional Original Income Effectivity Ratio. 3. Average of activity ratio (harmony) of Operation Cost and Capital Cost. 4. Average of growth ratio
\end{abstract}

Keywords : Regional independency, effectivity and Regional original income effecitivity.

\begin{abstract}
Abstrak
Penelitian ini bertujuan untuk mengetahui Kinerja Keuangan Pemerintah Kabupaten Bojonegoro dan Jombang tahun 2010 - 21014. Penelitian ini dilaksanakan di Kabupaten Bojonegoro dan Jombang, data yang digunakan diperoleh dengan cara dokumentasi atas laporan keuangan Anggaran Pendapatan Belanja Daerah (APBD) Kabupaten Bojonegoro dan Jombang. Teknik Analisis yang digunakan pada penelitian ini yaitu desriptif kuantitatif. Hasil analisis menunjukan bahwa Kinerja Keuangan Kabupaten Bojonegoro lebih unggul apabila dibandingkan Kabupaten Jombang Hal tersebut dapat dilihat dari : 1. Rata-rata Rasio. 2. Rata-rata Rasio Efektifitas PAD. 3.Rata-rata Rasio Aktivitas (keserasian) Belanja Operasi dan Belanja Modal. 4. Rata-rata Rasio
\end{abstract}

Kata kunci : Kemandirian Daerah, Efektifitas dan Efisiensi PAD.

\section{PENDAHULUAN}

Organisasi Pemerintah merupakan salah satu bentuk organisasi nonprofit yang bertujuan meningkatkan pelayanan kepada masyarakat umum yang dapat berupa peningkatan keamanan, peningkatan mutu pendidikan atau peningkatan mutu kesehatan dan lain-lain. Lembaga pemerintah melakukan berbagai bentuk pengeluaran guna membiayai kegiatan-kegiatan yang dilakukan disatu sisi dan disisi lain lembaga ini harus melakukan berbagai upaya untuk memperoleh penghasilan, salah satu upaya yang 
dapat dilakukan pemerintah dalam meningkatkan penghasilan adalah dengan mengoptimalkan Pendapatan Asli Daerah. Pendapatan asli daerah (PAD) merupakan semua penerimaan yang diperoleh daerah dari sumber-sumber dalam wilahnya sendiri yang dipungut berdasarkan peraturan daerah sesuai dengan peraturan perundang-undangan yang berlaku Pasal 1 Undang-Undang Nomor 33 Tahun 2004 (Halim, 2004:96). Dalam Undang-Undang Nomor 33 Tahun 2004 tentang perimbangan keuangan antara pemerintah pusat dan pemerintah daerah pada bab V (lima) nomor 1 (satu) disebutkan bahwa pendapatan asli daerah bersumber dari:

Pajak Daerah yaitu kontribusi wajib kepada Daerah yang terutang oleh orang pribadi atau badan yang bersifat memaksa berdasarkan Undang-Undang, dengan tidak mendapatkan imbalan secara langsung. Berdasarkan UU nomor 28 tahun 2009 pajak kabupaten/kota dibagi menjadi beberapa sebagai berikut, Pajak Hotel, Pajak Restoran, Pajak Hiburan, Pajak Reklame, Pajak Penerangan Jalan, Pajak Mineral bukan Logam dan Batuan, Pajak
Parkir, Pajak Air Tanah, Pajak Sarang Burung Walet, Pajak Bumi dan Bangunan Perdesaan dan Perkotaan, dan Pajak Bea Perolehan Hak atas Tanah dan Bangunan.

Retribusi Daerah

Menurut UU Nomor 28 Tahun 2009 secara keseluruhan terdapat 30 jenis retribusi yang dapat dipungut oleh daerah yang dikelompokkan ke dalam 3 golongan retribusi, yaitu retribusi jasa umum, retribusi jasa usaha, dan retribusi perizinan tertentu.

Hasil Pengelolaan Kekayaan Milik Daerah yang Dipisahkan

Undang-undang nomor 33 tahun 2004 mengklasifikasikan jenis hasil pengelolaan kekayaan daerah yang dipisahkan, dirinci menurut menurut objek pendapatan yang mencakup bagian laba atas penyertaan modal pada perusahaan milik daerah/BUMD, bagian laba atas penyertaan modal pada perusahaan milik negara/BUMN dan bagian laba atas penyertaan modal pada perusahaan milik swasta maupun kelompok masyarakat.

Undang-undang nomor 33 tahun 2004 mengklasifikasikan yang termasuk dalam pendapatan asli 
daerah yang sah meliputi: Hasil penjualan kekayaan daerah yang tidak dipisahkan, Jasa giro, Pendapatan bunga, Keuntungan adalah nilai tukar rupiah terhadap mata uang asing, Komisi, potongan, ataupun bentuk lain.

Kinerja Keuangan menurut Tampubolon (2005:45) yaitu: "Pengukuran kinerja instansi yang ditimbulkan sebagi akibat dari proses pengambilan keputusan manajemen karena menyangkut pemanfaatan modal, efisiensi dan rentabilitas dari kegiatan instansi”. Kinerja keuangan yaitu alat untuk mengukur prestasi kerja keuangan instansi melalui struktur permodalannya. Penilaian kinerja instansi harus diketahui output maupun inputnya. Output adalah hasil dari suatu kinerja karyawan atau instansi, sedangkan input adalah keterampilan atau alat yang digunakan untuk mendapatkan hasil tersebut.

Menurut Sartono (2001：111) bahwa alat analisis kinerja yang selama ini banyak digunakan antara lain adalah rasio keuangan, rasio metode radar, balanced scorecard dan Economic Value Added.
Pengukuran atas kinerja keuangan pemerintah daerah dapat digunakan sebagai pedoman bagi pemerintah daerah untuk mengelola keuangan daerah pada masa yang akan datang, sebagai alat pengawas bagi masyarakat terhadap kebijakan yang telah dipilih atas pelaksanaan anggaran daerah.

Selajutnya terkait dengan pengukuran atas kinerja keuangan pemerintah daerah dilakukan dengan membandingkan hasil yang telah dicapai pada suatu periode dibandingkan dengan periode sebelumnya sehingga dapat diketahui bagaimana kecenderungan atas kinerja keuangan yang telah terjadi. Beberapa rasio yang digunakan untuk mengukur kinerja keuangan pemerintah daerah berdasarkan data keuanga yang dimiliki dan bersumber pada APBD antara lain rasio kemandirian (otonomi fiskal), rasio efektivitas dan efisiensi serta debt service coverage ratio. (Halim, 2002:150).

Menurut Halim (2002:232), kemandirian keuangan daerah (otonomi fiskal) menunjukkan kemampuan Pemerintah Daerah dalam membiayai sendiri kegiatan 
pemerintahan, pembangunan dan pelayanan. Kemandirian keuangan daerah ditunjukkan oleh besar kecilnya pendapatan asli daerah dibandingkan dengan pendapatan daerah yang berasal dari sumber yang lain, misalnya bantuan pemerintah pusat ataupun dari pinjaman. Rasio Kemandirian Keuangan Daerah diukur menggunakan:

$$
\mathrm{RKKD}=\frac{\mathrm{PAD}}{\mathrm{BPP}} \times 100 \%
$$

Keterangan :

RKKD : Rasio Kemandirian

PAD : Pendapatan Asli Daerah

BPPP : Bantuan Pemerintah Pusat

Tabel 1. Tingkat Kemandirian

\section{Daerah}

\begin{tabular}{ccc}
\hline $\begin{array}{c}\text { Kemampuan } \\
\text { Keuangan }\end{array}$ & $\begin{array}{c}\text { Rasio } \\
\text { Kemandirian }\end{array}$ & $\begin{array}{c}\text { Pola } \\
\text { Hubungan }\end{array}$ \\
\hline $\begin{array}{c}\text { Rendah } \\
\text { Sekali }\end{array}$ & $0-25 \%$ & Instruktif \\
\hline Rendah & $25-50 \%$ & Konsultatif \\
\hline Sedang & $50-75 \%$ & Partisipatif \\
\hline Tinggi & $75-100 \%$ & Delegatif \\
\hline
\end{tabular}

Sumber: Purba, 2012

$$
\text { Rasio }
$$

Kemandirian

menggambarkan ketergantungan daerah terhadap sumber dana ekstern. Semakin tinggi rasio kemandirian mengandung arti bahwa tingkat ketergantungan daerah terhadap bantuan pihak ekstern (terutama pemerintah pusat dan propinsi) semakin rendah, dan demikian pula sebaliknya. Tingkat Kemandirian Keuangan Daerah dapat dilihat pada tabel berikut:

\section{Pengelolaan Keuangan Daerah} adalah keseluruhan kegiatan yang berkaitan dengan kemampuan daerah yaitu meliputi perencanaan, pelaksanaan, penatausahaan, pelaporan, pertanggung jawaban, dan pengawasan keuangan daerah. Kemampuan atau kemandirian pada suatu daerah yang dimaksud adalah sampai sejauh mana daerah dapat menggali sumber-sumber keuangan sendiri guna membiayai kebutuhan keuangan daerah tanpa harus menggantungkan diri pada bantuan dan subsidi dari pemerintah pusat. Kemampuan pemerintah daerah dalam mengelola keuangan tercermin dalam Anggaran Pendapatan Belanja Daerah (APBD) yang menggambarkan kemampuan pemerintah daerah dalam membiayai kegiatan pelaksanaan tugas pembangunan, serta pemerataan dan keadilan dengan mengembangkan seluruh potensi yang dimiliki oleh masing-masing daerah. 
Rasio Efektifitas menunjukan kemampuan daerah dalam merealisasikan pendapatan asli daerah yang direncanakan dibandingkan dengan target yang ditetapkan berdasarkan potensi riil daerah. Pengukuran rasio efektifitas dapat dilihat pada tabel berikut:

Tabel 2. Tingkat Efektifitas PAD

\begin{tabular}{cc}
\hline Eefektivitas PAD & Rasio Efektivitas \\
\hline Efektif & $>100 \%$ \\
\hline Efektif Berimbang & 1 \\
\hline Tidak Efektif & $<100 \%$
\end{tabular}

Sumber:Mahsum, 2006

Kemampuan daerah dalam menjalankan tugas dikategorikan efektif apabila rasio yang dicapai mencapai minimal 100 persen. Guna memperoleh ukuran yang lebih baik, rasio efektivitas perlu diperbandingkan dengan rasio efisiensi yang dicapai pemerintah daerah.

Rasio efisiensi adalah rasio yang menggambarkan perbandingan antara besarnya biaya yang dikeluarkan untuk memperoleh pendapatan dengan realisasi pendapatan yang diterima. Kinerja pemerintah daerah dalam melakukan pemungutan pendapatan dikategorikan efisien apabila rasio yang dicapai kurang dari 100 persen. Semakin kecil rasio efisiensi berarti kinerja pemerintah daerah semakin baik. Pengukuran rasio efisiensi keuangan daerah dapat dilihat pada tabel 3 berikut.

Tabel 3. Tingkat Efisiensi Keuangan Daerah

\begin{tabular}{|c|c|}
\hline $\begin{array}{c}\text { Efisiensi } \\
\text { Keuangan Daerah }\end{array}$ & Rasio Efektivitas \\
\hline Tidak Efisien & $>100 \%$ \\
\hline Kurang Efisien & $90 \%-100 \%$ \\
\hline Cukup Efisien & $80 \%-90 \%$ \\
\hline Efisien & $60 \%-80 \%$ \\
\hline Sangat Efisien & $<60 \%$ \\
\hline \multicolumn{2}{|c|}{ Sumber:Abdul Halim, 2007} \\
\hline \multicolumn{2}{|c|}{ Rasio aktifitas keserasian adalah } \\
\hline rasio & menggambarkan \\
\hline bagaimana $\quad p$ & emerintah \\
\hline memprioritaskan & alokasi dananya \\
\hline pada belanja & rutin dan belanja \\
\hline pembangunan & optimal. \\
\hline
\end{tabular}

Semakin tinggi persentase dana yang dialokasikan untuk belanja rutin berarti persentase belanja investasi (belanja pembangunan) yang digunakan untuk menyediakan sarana prasarana ekonomi masyarakat cenderung semakin kecil Rasio Pertumbuhan (Growth Ratio) mengukur seberapa besar 
kemampuan pemerintah daerah dalam mempertahankan dan meningkatkan keberhasilannya yang telah dicapai dari periode ke periode berikutnya. Dengan diketahuinya pertumbuhan untuk masing-masing komponen sumber pendapatan dan pengeluaran, dapat digunakan mengevaluasi potensi-potensi mana yang perlu mendapatkan perhatian.

Kabupaten Bojonegoro merupakan salah satu kabupaten di Wilayah Jawa Timur yang memiliki wilayah cukup yang luas serta potensi alam yang mendukung. Kabupaten Bojonegoro memiliki potensi-potensi wilayah yang mendukung peningkatan atas kinerja keuangan daerah. Salah satu penerimaan pendapatan asli daerah (PAD) berasal dari sektor pajak daerah. Salah satu komponen pajak daerah yang perlu mendapatkan perhatian lebih oleh Pemerintah Kabupaten Bojonegoro adalah pajak mineral bukan logam dan batuan. Hal itu dikarenakan Kabupaten Bojonegoro menyimpan kekayaan pertambangan non migas yaitu bahan-bahan mineral bukan logam dan batuan. Berbeda dengan Kabupaten Jombang dimana wilayah tersebut juga memiliki potensi sumber pendapatan yang tinggi khususnya pada sektor perdagangan. Tujuan penelian ini adalah untuk mendeskripsikan dan menganalisis perbandingan kinerja keuangan pemerintah Kabupaten Bojonegoro dan Jombang Tahun 2010-2014 dilihat dari rasio kemandirian keuangan daerah, rasio efektifitas dan efisiensi Pendapatan Asli Daerah, rasio keserasian dan rasio pertumbuhan.

\section{METODE PENELITIAN}

Penelitian yang penulis lakukan adalah penelitian yang bersifat studi kasus, menurut Indriantoro dan Supomo (2002: 146), yaitu penelitian yang berisikan paparan atau data yang relevan dari hasil penelitian pada obyek penelitian yang mencoba mengetahui dan memecahkan permasalahan yang dihadapi instansi. Sedangkan prosedur pemecahan masalah pada penelitian ini menggunakan metode deskriptif, yaitu dengan menggambarkan keadaan yang menjadi fokus dalam penelitian ini berdasarkan data yang telah dikumpulkan. 
Untuk memperoleh dan mengumpulkan data-data sekunder maka peneliti menggunakan metode pengumpulan data melalui dokumentasi. Langkah ini berupa kegiatan mengumpulkan data-data sekunder dengan cara melihat atau menyalin catatan kertas kerja yang dianggap berhubungan dengan penelitian yang meliputi laporan keuangan Pemerintah Daerah pada Kabupaten Bojonegoro dan Jombang.

\section{PEMBAHASAN}

\section{Rasio Kemandirian Keuangan \\ Daerah}

Hasil analisis rasio kemandirian pada Kabupaten Bojonegoro dan Kabupaten Jombang Tahun 20102014 dapat dilihat pada tabel berikut:

Tabel 4. Hasil Rasio Kemandirian

Tahun 2010 sampai 2014

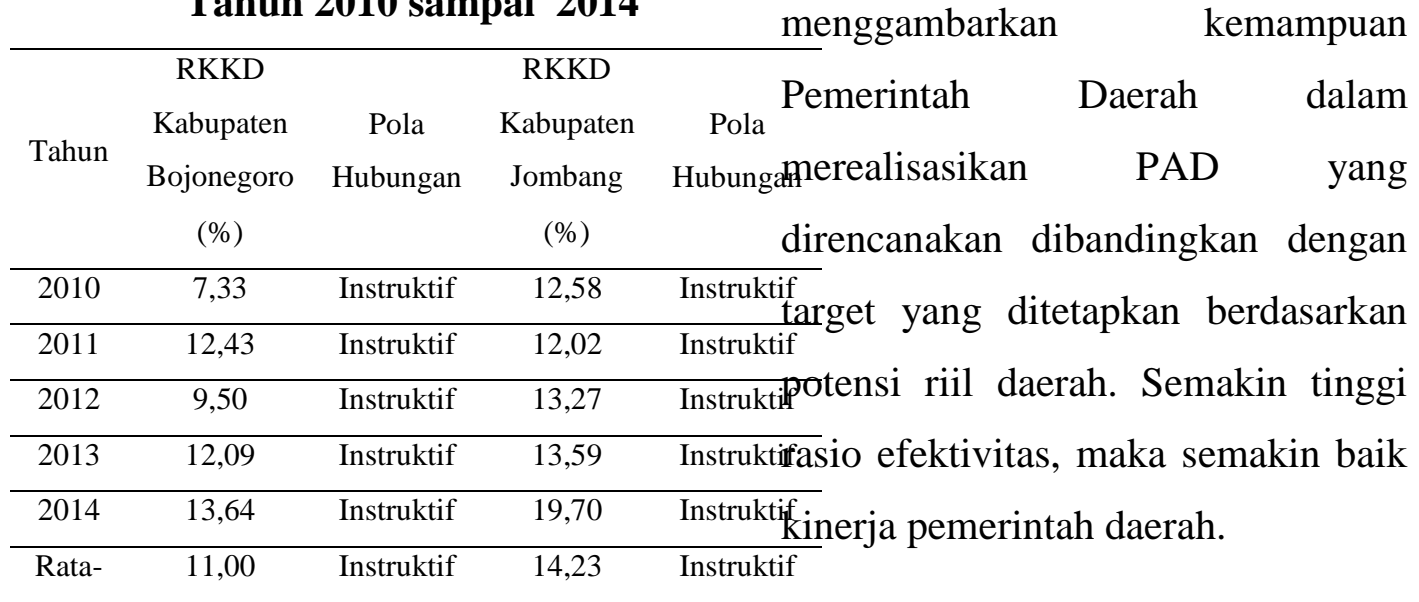

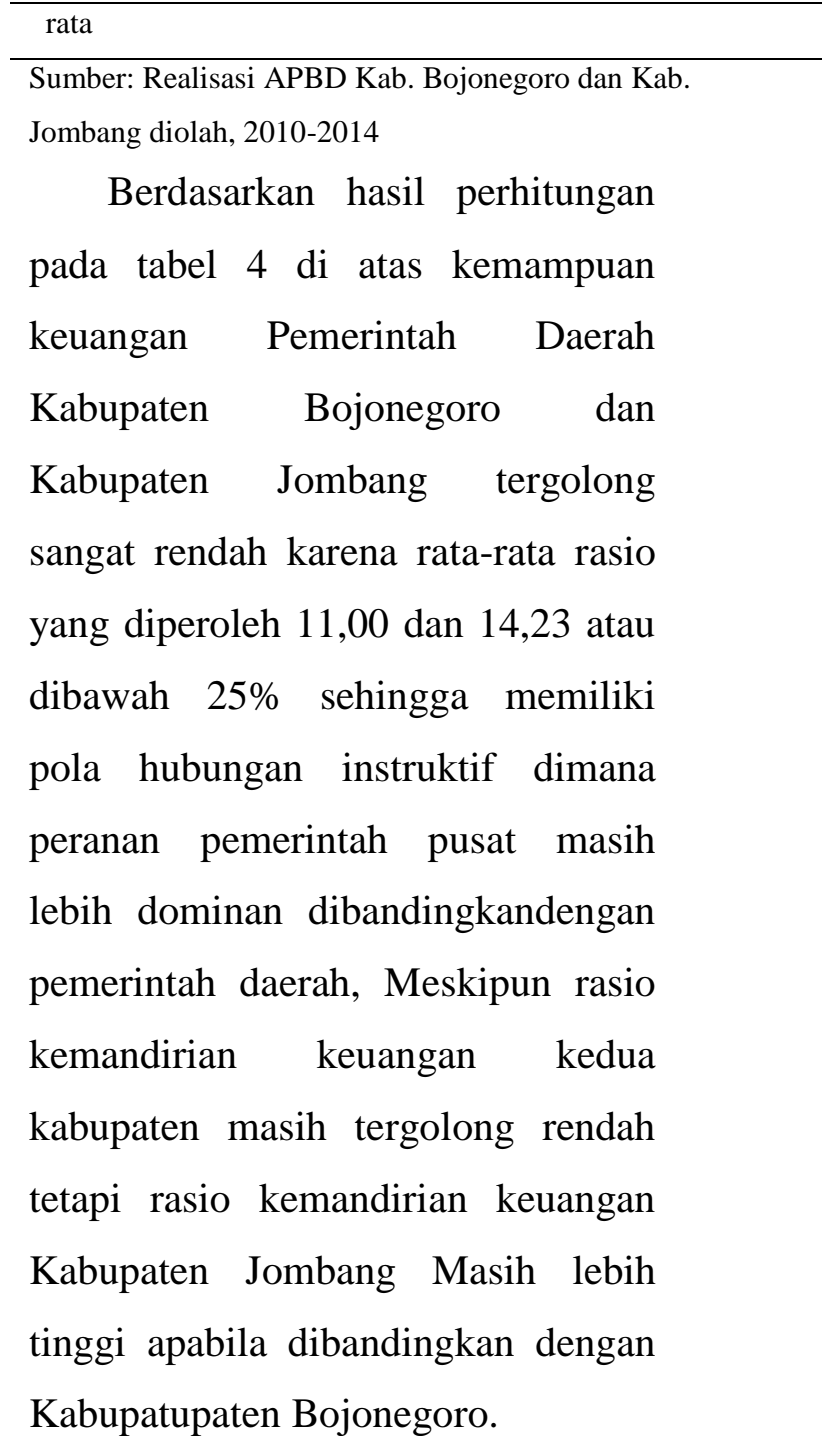

2. Rasio Efektifitas dan Efisiensi PAD

Rasio Efektivitas PAD menggambarkan kemampuan

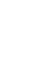


Hasil analisis Rasio Efektifitas dan Efisiensi Pendapatan Asli Daerah pada Pemerintah Daerah Pada Kabupaten Bojonegoro dan Kabupaten Jombang Tahun 20102014 dapat dilihat pada tabel berikut:

Tabel 5. Hasil Rasio Efektifitas PAD Tahun 2010 sampai 2014

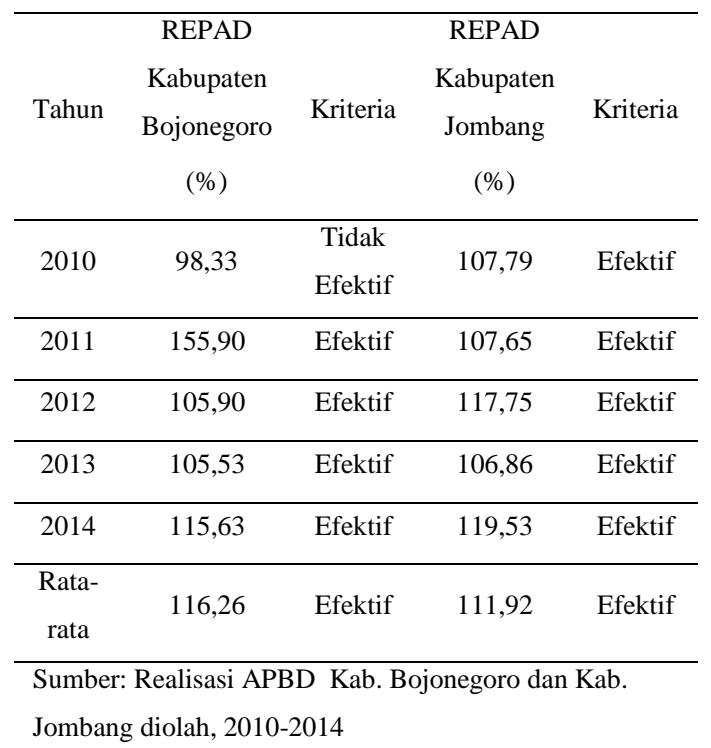

Efektivitas Keuangan Pemerintah

Kabupaten Bojonegoro pada tahun 2010 tidak efektif, karena nilai yang diperoleh masih di bawah 100\% yaitu 98,33\%. Untuk tahun 2011, 2012, 2013 dan 2014 sudah masuk dalam kategori efektif karena nilai yang diperoleh sudah lebih dari $100 \%$ yaitu $155,90 \%, 105,90 \%$, 105,53 dan 115,63\%. Sementara Rasio Efektivitas Pemerintah Daerah Kabupaten Jombang dari tahun 2010,
2011, 2012, 2013 dan 2014 memiliki hasil yang tergolong Efektif dengan nilai rasio yang diperoleh masingmasing $107,79 \%, \quad 107,65 \%$, $117,74 \%, 106,86 \%$ dan $119,53 \%$.

Dengan demikian dapat membuktikan bahwa kemampuan Pemerintah Daerah Kabupaten Bojonegoro dan Kabupaten Jombang tahun 2010 - 2014 mampu merealisasikan Pendapatan Asli Daerah yang bersumber dari pendapatan pajak, pendapatan retribusi, pendapatan hasil perusahaan milik daerah dan hasil pengelolaan kekayaan daerah yang dipisahkan.

\section{Tabel 6. Hasil Rasio Efefisiensi \\ PAD Tahun 2010 sampai 2014}

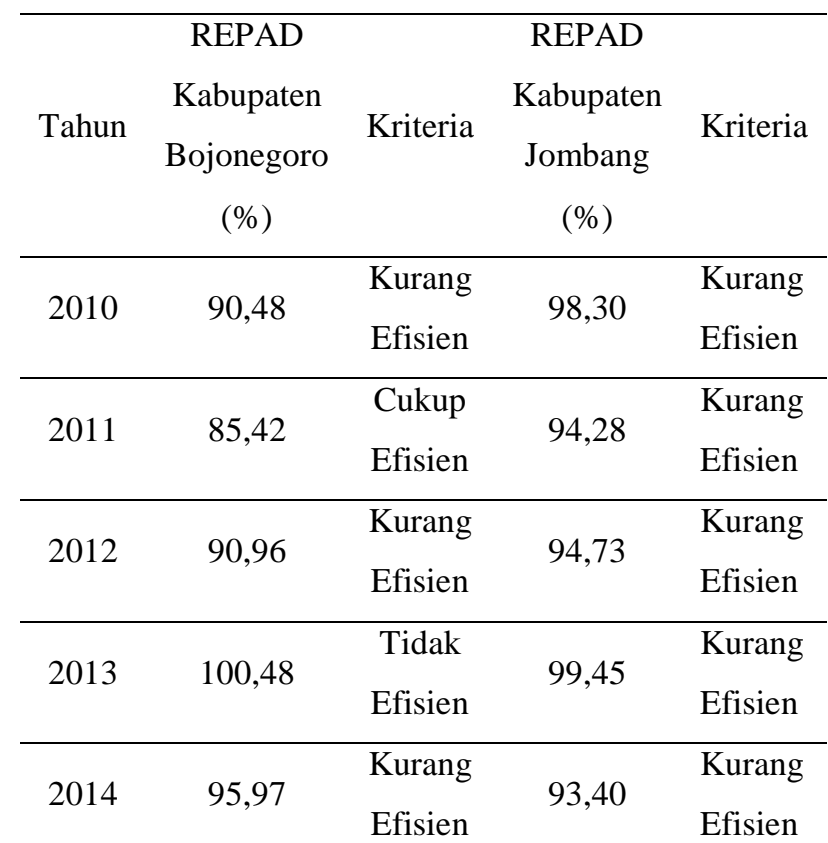




\begin{tabular}{|c|c|c|c|c|}
\hline $\begin{array}{l}\text { Rata- } \\
\text { rata }\end{array}$ & 92,66 & $\begin{array}{l}\text { Kurang } \\
\text { Efisien }\end{array}$ & 96,03 & $\begin{array}{l}\text { KurangTahun } 2010-2014 \text { dapat dilihat pada } \\
\text { Efisien }{ }_{\text {tabel berikut: }}\end{array}$ \\
\hline
\end{tabular}

Sumber: Realisasi APBD Kab. Bojonegoro dan Kab.

Jombang diolah, 2010-2014

Berdasarkan pada tabel 6 diatas

Efisiensi Keuangan Daerah

Kabupaten Bojonegoro pada tahun 2010, 2012 dan 2014 tergolong kurang Efisien karena interval efisiensinya diantara 90\%-100\%. Hal tersebut terjadi karena realisai pendapatan lebih besar daripada realisasi belanja daerah. Tahun 2011 tergolong cukup efisien karena interval efisienya diantara $80 \%-90 \%$ dan tahun 2013 tidak efisien karena rasio efisiensinya melebihi $100 \%$. Sementara itu Efiensi keuanagan daerah kabupaten Jombang dari tahun 2010 sampai 2014 tergolong kurang efisien.

\section{Rasio Aktivitas Keserasian Kabupaten Bojonegoro dan Jombang}

Rasio aktivitas Keserasian menggambarkan bagaimana pemerintah daerah memprioritaskan alokasi dananya pada belanja operasi dan belanja modal secara optimal.

Hasil perhitungan rasio keseerasian belanja operasional dan belanja modal pada Kabupaten Bojonegoro dan Kabupaten Jombang

\section{Tabel 7. Hasil Rasio Belanja Operasional Tahun} 2010 sampai 2014

\begin{tabular}{ccc}
\hline Tahun & $\begin{array}{c}\text { Rasio Belanja } \\
\text { Operasional } \\
\text { Kabupatan } \\
\text { Bojonegoro }\end{array}$ & $\begin{array}{c}\text { Rasio Belanja } \\
\text { Operasional } \\
\text { Kabupatan } \\
\text { Jombang }\end{array}$ \\
\hline 2010 & $89,32 \%$ & $87,66 \%$ \\
\hline 2011 & $90,61 \%$ & $89,29 \%$ \\
\hline 2012 & $85,18 \%$ & $81,02 \%$ \\
\hline 2013 & $84,37 \%$ & $81,18 \%$ \\
\hline 2014 & $77,66 \%$ & $75,90 \%$ \\
\hline Rata-rata & $85,43 \%$ & $83,01 \%$ \\
\hline Sumber: Realisasi APBD Kab. Bojonegoro dan \\
\multicolumn{2}{l}{ Kab. Jomban diolah, 2010-2014 }
\end{tabular}

Berdasarkan hasil perhitungan pada tabel 7 di atas diketahui bahwa rata-rata Rasio Keserasian Belanja Operasi Kabupaten Bojonegoro 85,43\%. Dimulai pada tahun 2010 di mana rasio nya sebesar $89,32 \%$ meningkat pada tahun 2011 menjadi 90,61\%, kemudian dari tahun 2012 sampai 2014 mengalami peurunan menjadi $85,18 \%$ pada tahun 2012, $84,37 \%$ dan pada tahun 2014 juga mengalami penurunan menjadi $77,66 \%$.

Sementara itu rata-rata keserasian belanja operasi Kabupaten Jombang sebesar 83,01\% Dimulai pada tahun 2010 di mana rasio nya sebesar 89,32\% meningkat pada 
tahun 2011 menjadi 89,29\%, kemudian pada tahun 2012 mengalami penurunan menjadi $81,02 \%$, pada tahun 2013 mengalami kenaikan menjadi $81,18 \%$ dan pada tahun 2014 kembali mengalami penurunan menjadi 75,90\%.. Hasil Rasio Belanja Modal dapat dilihat pada tabel berikut:

Tabel 8. Hasil Rasio Belanja Modal Tahun 2010 sampai 2014

\begin{tabular}{ccc}
\hline Tahun & $\begin{array}{c}\text { Rasio Belanja } \\
\text { Modal } \\
\text { Kabupatan } \\
\text { Bojonegoro }\end{array}$ & $\begin{array}{c}\text { Rasio Belanja } \\
\text { Modal } \\
\text { Kabupatan } \\
\text { Jombang }\end{array}$ \\
\hline 2010 & $10,53 \%$ & $7,86 \%$ \\
\hline 2011 & $9,20 \%$ & $6,00 \%$ \\
\hline 2012 & $14,62 \%$ & $14,28 \%$ \\
\hline 2013 & $15,51 \%$ & $13,92 \%$ \\
\hline 2014 & $22,25 \%$ & $19,95 \%$ \\
\hline Rata-rata & $10,02 \%$ & $12,44 \%$ \\
\hline Sumb: Realisasi APBD Kab. Bojonegor
\end{tabular}

Sumber: Realisasi APBD Kab. Bojonegoro dan Kab. Jombang diolah,2010-2014

Pada tabel di atas diketahui bahwa rata-rata Rasio Keserasian Belanja Modal Kabupaten Bojonegoro 14,43\%. Dimulai pada tahun 2010 di mana rasio nya sebesar $10,53 \%$ menurun pada tahun 2011 menjadi $9,20 \%$, kemudian dari tahun 2012 sampai 2014 mengalami peningkatan menjadi $14,62 \%$ pada tahun $2012,15,51 \%$ pada tahun dan pada tahun 2014 juga mengalami peningkatan menjadi $22,25 \%$.

Sementara itu rata-rata keserasian belanja operasi Kabupaten Jombang sebesar 12,40\% Dimulai pada tahun 2010 di mana rasio nya sebesar 7,86\% menurun pada tahun 2011 menjadi 6,00\%, kemudian pada tahun 2012 mengalami peningkatan menjadi 14,28\%, pada tahun 2013 mengalami penurunan kembali menjadi $14,28 \%$ dan pada tahun 2014 kembali mengalami kenaikan menjadi $19,95 \%$.

\section{Rasio Pertumbuhan Kabupaten}

\section{Bojonegoro dan Jombang}

Hasil perhitungan rasio belanja petubuhan pada Kabupaten Bojonegoro dan Kabupaten Jombang Tahun 2010-2014 dapat dilihat pada tabel 9 berikut:

Tabel 9. Hasil Rasio Pertumbuhan 2010 sampai 2014

\begin{tabular}{ccc}
\hline Tahun & $\begin{array}{c}\text { Hasil Rasio } \\
\text { Pertumbuhan } \\
\text { Kab. } \\
\text { Bojonegoro }\end{array}$ & $\begin{array}{c}\text { Hasil Rasio } \\
\text { Kertumbuhan } \\
\text { Kab. Jombang }\end{array}$ \\
\hline 2010 & $13,75 \%$ & $20,99 \%$ \\
\hline 2011 & $106,01 \%$ & $14,33 \%$ \\
\hline 2012 & $(3,24 \%)$ & $31,72 \%$ \\
\hline 2013 & $35,49 \%$ & $12,59 \%$ \\
\hline 2014 & $34,98 \%$ & $64,28 \%$ \\
\hline Rata- & $37,40 \%$ & $28,78 \%$ \\
\hline
\end{tabular}




\begin{abstract}
rata
Sumber: Realisasi APBD Kab. Bojonegoro dan Kab. Jombang 2010-2014

Dari hasil perhitungan pada tabel diatas dapat diketahui bahwa rasio pertumbuhan Pemerintah Daerah Kabupaten Bojonegoro Tahun 2010-2014 menunjukkan adanya rasio pertumbuhan yang cenderung fluktuatif dimulai pada tahun 2010 dengan nilai 13,75\% naik mencapai $106,10 \%$ pada tahun 2011 tetapi pada tahun 2012 kembali mengalami penurunan hingga minus 3,24\%, pada tahun 2013 naik menjadi $35,49 \%$ kemudian tahun 2014 mengalami penurunan menjadi $34,98 \%$.
\end{abstract}

Sama halnya dengan Kab. Bojonegoro rasio pertumbuhan Kab. Jombang setiap tahunnya juga fluktuatif dimulai pada tahun 2010 dengan nilai $20,99 \%$ turun menjadi 14,33\% pada tahun 2011 namun pada tahun 2012 kembali naik menjadi $31,72 \%$, kemudian pada tahun 2013 turun lagi menjadi 12,59\% kemudian tahun 2014 naik kembali menjadi $64,28 \%$.

\section{PENUTUP}

Berdasarkan penelitian yang sudah dilakukan penulis mengenai kinerja keuangan pemerintah Kabupaten Bojonegoro dan Jombang Tahun 2010-2014, maka penulis menarik kesimpulan sebagai berikut :

Kemandirian Keuangan Daerah Kabupaten Bojonegoro dan Jombang Tahun 2010-2014 masuk dalam kategori rendah sekali karena ratarata Rasio yang dicapai sebesar $11.00 \%$ dan $14,23 \%$ atau masih dibawah $25 \%$ yang berarti memiliki pola hubungan Instruktif, hal tersebut menunjukan bahwa tingkat ketergantungan pemerintah Kabupaten Bojonegoro dan Jombang terhadap bantuan dari pihak Ektern masih cukup tinggi. Namun apabila dibandingkan antara kedua kabupaten maka tingkat Kemandirian keuangan Kabupaten Jombang lebih unggul dari Kabupaten Bojonegoro.

Efektifitas Pendapatan Asli Daerah Kabupaten Bojonegoro dan Jombang Tahun 2010-2014 dapat dikatakan efektif hal tersebut dikarenakan rata-rata rasio yang telah dicapai adalah 116,26\% dan $111,92 \%$ lebih dari 100\%. Dari nilai rasio yang di peroleh menunjukan bahwa Kabupaten Bojonegoro lebih 
efektif dalam mengelola Pendapatan Asli Daerah.

Efisiensi Keuangan Daerah Kabupaten Bojonegoro dan Jombang dikategorikan kurang efisien karena rata-rata interval efisiensinya diantara 90\%-100\% yaitu sebesar 92,66 dan 96,03. Dari hasil perhitungan menunjukan bahwa Kabupaten Bojonegoro Lebih Efisisn dalam Mengelola Keuangan Daerah dibandingkan Kabupaten Jombang.

Secara umum Pemerintah

Daerah Kabupaten Bojonegoro Tahun 2010-2014 sebagaian besar dana yang dimiliki masih diprioritaskan untuk kebutuhan belanja operasional, sementara Pemerintah Daerah Kabupaten Jombang lebih memprioritaskan kebutuhan belanja modal hal ini dapat dilihat pada rata-rata rasio belanja operasional sebesar $85,43 \%$ dan $83,01 \%$ sementara rata-rata rasio belanja operasional sebesar $10,02 \%$ dan $12,44 \%$.

Rasio Pertumbuhan

Rasio pertumbuhan antara kabupaten Bojonegoro dan Jombang mengalami peningkatan, namun ratarata pertumbuhan pemerintah Kabupaen Bojonegoro lebih tinggi dibandingkan dengan Kabupaten Jombang yaitu sebesar $37,40 \%$ dan $28,78 \%$.

Dari kesimpulan diatas menunjukan bahwa Kinerja Keuangan Pemerintah Kabupaten Bojonegoro lebih unggul apabila dibandingkan dengan Kinerja Keuangan Pemerintah Kabupaten Bojonegoro.

\section{DAFTAR PUSTAKA}

Halim, Abdul. 2002. Akuntansi Sektor Publik Akuntansi Keuangan Daerah, Penerbit Salemba Empat, Jakarta. 2004. Akuntansi

Keuangan Daerah. Salemba Empat. Jakarta.

Sektor Publik: Akuntansi Keuangan Daerah. Jakarta : Salemba Empat.

Indriantoro dan Supomo. 2002, Metodologi Penelitian Bisinis Untuk Akuntansi dan Manajemen, Edisi Pertama, Penerbit BPFE, Yogyakarta.

Mohammad Mahsun. 2009.

Pengukuran Kinerja Sektor

Publik. Yogyakarta : BPFE. 
Analisis Perbandingan Kinerja Keuangan Pemerintah...... (Jaenuri)

Sartono, Agus. 2001. Manajemen

Keuangan Teori dan Aplikasi,

Edisi Keempat, Cetakan

Pertama, Penerbit BPFE,

Yogyakarta.

Sijabat, Mentari Yosephen. Saleh, Choirul dan Wachid, Abdul. 2014. Analisis Kinerja

Keuangan Serta Kemampuan

Keuangan Pemerintah Daerah

Dalam Pelaksanaan Otonomi

Daerah (Studi pada Dinas

Pendapatan Daerah dan Badan

Pengelola Keuangan dan Aset

Daerah Kota Malang Tahun

Anggaran 2008-2012)

Tampubolon, Manahan. 2005.

$\begin{array}{lr}\text { Manajemen } & \text { Keuangan } \\ \text { (Finance } & \text { Management), }\end{array}$

Cetakan Pertama, Penerbit

Ghalia Indonesia: Bogor.

Undang-Undang Nomor 28 Tahun

2009 tentang Pajak Daerah dan

Retribusi

Daerah.http://eodb.ekon.go.id/d

ownload/peraturan/undangunda

ng/UU_28_2009.PDF. Di

Unduh 12 April 2016

Undang-Undang Nomor 33 Tahun

2004 tentang Perimbangan

Keuangan antara Pemerintah

Pusat dan Pemerintah Daerah.

http://www.itjen.depkes.go.id/p

ublic/upload/unit/pusat/files/Un dang-

undang/uu2004_33(imbangkeu

PusDa).pdf. Di Unduh 12 April

2016 